\title{
Urbanisation is associated with reduced Nosema sp. infection, higher colony strength and higher richness of foraged pollen in honeybees
}

\author{
Ash E. SAMUelson ${ }^{1}$, Richard J. Gill ${ }^{2}$, Ellouise LeAdBeater ${ }^{1}$ \\ ${ }^{1}$ School of Biological Sciences, Royal Holloway University of London, Egham, UK \\ ${ }^{2}$ Department of Life Sciences, Imperial College London, Silwood Park Campus, Ascot, UK \\ Received 11 August 2019 - Revised 12 February 2020 - Accepted 26 February 2020
}

\begin{abstract}
Bees are vital pollinators, but are faced with numerous threats that include loss of floral resources and emerging parasites amongst others. Urbanisation is a rapidly expanding driver of land-use change that may interact with these two major threats to bees. Here we investigated effects of urbanisation on food store quality and colony health in honeybees (Apis mellifera) by sampling 51 hives in four different land-use categories: urban, suburban, rural open and rural wooded during two seasons (spring and autumn). We found positive effects of urban land use on colony strength and richness of stored pollen morphotypes, alongside lower late-season Nosema sp. infection in urban and suburban colonies. Our results reveal that honeybees exhibit lower colony performance in strength in rural areas, adding to the growing evidence that modern agricultural landscapes can constitute poor habitat for insect pollinators.
\end{abstract}

urbanisation / Nosema spp. / Varroa destructor / pollen foraging / colony strength

\section{INTRODUCTION}

Honeybees (Apis mellifera L.) pollinate a significant proportion of the world's crops and wild plants (Grünewald 2010). Therefore, reports of environmental threats to honeybees have generated concern regarding provision of pollination services, particularly as demand for pollination increases (Aizen and Harder 2009). Several threats to honeybee stocks have been implicated, including habitat loss and the associated lack of forage (Couvillon et al. 2014b; Alaux et al. 2017),

Electronic supplementary material The online version of this article (https://doi.org/10.1007/s13592-020-00758-1) contains supplementary material, which is available to authorized users.

Corresponding author: A. Samuelson, ash.samuelson.2014@live.rhul.ac.uk

Manuscript editor: Cedric Alaux parasites and disease (Brosi et al. 2017), and environmental contaminants such as pesticides (Henry et al. 2012; Wood and Goulson 2017).

While numbers of managed hives in the UK (Alton and Ratnieks 2013) and some parts of Europe (Potts et al. 2010; Breeze et al. 2014) have declined in recent decades, urban areas may be an exception due largely to an increase in popularity of urban beekeeping (Alton and Ratnieks 2013; Lorenz and Stark 2015). In London, the number of beekeepers rose from 464 to 1237 between 2008 and 2013 and the number of hives doubled to over 3500 (Alton and Ratnieks 2013), while in Berlin, the number of beekeepers increased by $53 \%$ and hives by $44 \%$ between 2006 and 2012 (Lorenz and Stark 2015). At the same time, urban areas are expanding, with a three-fold increase in global urban land cover estimated between 2000 and 2030 (Seto et al. 2012) and a predicted increase in global human urban population from 55 
to $68 \%$ between 2018 and 2050 (United Nations 2018). Honeybees and other pollinators are therefore likely to come into increasing contact with cities in the future. However, research to date has generated mixed results regarding the effect of urbanisation on honeybee colony success (Sponsler and Johnson 2015; Garbuzov et al. 2015b; Lecocq et al. 2015; Youngsteadt et al. 2015).

Urban areas may offer more abundant and consistent forage than intensive agricultural areas in the form of flowering plants in gardens and parks (Goddard et al. 2010; Samuelson et al. 2018, 2019). Pollen is an important food source for a honeybee colony, providing protein, lipids and micronutrients essential for colony development (Keller et al. 2005). However, most research on the effects of land use on honeybee nutrition focusses on nectar (e.g. Lecocq et al. 2015). Because the nutritional quality of pollen diet varies widely depending on the contribution of different plant species (Keller et al. 2005), land use is likely to have a strong effect on pollen diet quality (Donkersley et al. 2014). Urban areas may provide a diverse range of pollen sources (Garbuzov and Ratnieks 2014), which may have implications for colony health (Di Pasquale et al. 2013; Smart et al. 2016; Dolezal and Toth 2018), but to our knowledge, no study to date has demonstrated whether urbanisation affects the diversity of pollen collected by honeybees. Urbanisation also interacts with parasite and disease stressors (Dolezal and Toth 2018), with initial evidence indicating that some honeybee (Youngsteadt et al. 2015) and bumblebee (Goulson et al. 2012; Theodorou et al. 2016) diseases may be more prevalent in urban areas. This may be mediated by higher hive densities (Alton and Ratnieks 2013; Brosi et al. 2017), resource patchiness (Youngsteadt et al. 2015), temperature differences (Gago et al. 2013) and differences in beekeeper experience and practices in urban and rural areas (Alton and Ratnieks 2013).

Here we investigate a set of colony-level measures in an extensive network of 51 honeybee hives located across a gradient of urbanisation in South East England at two time points during the foraging season. To investigate the association between urbanisation and parasitisation, we measured Nosema sp. prevalence, a common microsporidian gut parasite of the honeybee (Fries et al. 2013), and infestation by the Varroa destructor mite, arguably the greatest current parasite threat to honeybee populations (Genersch 2010; Brosi et al. 2017). To investigate effects on foraging, we analysed the composition and morphotype diversity of pollen collected by bees in different land-use types.

\section{MATERIALS AND METHODS}

\subsection{Site selection}

Of the initial 123 beekeeper applications to participate in the experiment, we selected 51 study apiaries located across a gradient of urbanisation in South East England with the aim to maximise spatial independence and land-use type representativeness while also minimising collinearity of covariates. Apiaries using hive types other than National, Commercial, Langstroth and WBC hives were excluded from the study, as were commercial beekeepers (which made up a small proportion of beekeeper applications, and for whom beekeeping practices may differ from hobby beekeepers). Preliminary data exploration showed collinearity between apiary size (number of hives) and land use, and beekeeper experience and land use, with larger apiaries and more experienced beekeepers in rural areas (see Supplementary Material). Furthermore, several sites were nonindependent $(<6000 \mathrm{~m}$ apart; foraging ranges likely to overlap; Samuelson et al. 2019). To eliminate both issues, the following site selection protocol was carried out. Where two or more sites were less than $6000 \mathrm{~m}$ apart, only one site was chosen to be in the study based on the following objectives (in order): (1) maximising number of sites, (2) balanced representation of land-use types, (3) minimising collinearity (e.g. rural apiaries with few hives were preferred to those with many) and (4) maximising geographical spread.

\subsection{Land-use classification}

We classified land use at a radius of $3000 \mathrm{~m}$ around each site (radius based on the 99th percentile of waggle dance communicated distances 
from a separate study; Samuelson, Schuerch and Leadbeater, unpublished data). Classification was carried out in QGIS v2.16 following methods outlined in Samuelson and Leadbeater (2018). Briefly, land-use patches were defined by drawing polygons in QGIS over a satellite imagery baselayer (Bing Maps) and categorised visually to one of 29 land-use classes. Each land-use class was then coded to one of seven categories (impervious surface, domestic infrastructure, tree cover, gardens, open land, road and agricultural land) and the total area of each category within each site calculated. A PCA was performed to reduce the dimensionality of the land-use variables, and cluster analysis (Ward's method with a minimum cluster size of five; Bunce et al. 1996; Hall and Arnberg 2002; Owen et al. 2006) was performed on the first two principle components (defined as urban-ness and openness), which in combination captured $82.2 \%$ of the variation. Four clear clusters emerged (Figure 1), comprising a group characterised by high urban-ness scores with mid-level openness scores (urban, $n=13$ colonies), a group with high urban-ness and high openness scores (suburban, $n=13$ colonies), a group with low urban-ness and high openness (rural open, $n=13$ colonies) and a group with low urban-ness and low openness (rural wooded, $n=12$ colonies). This grouping was used as a categorical land-use variable in all subsequent analyses.

\subsection{Sample collection}

Two periods of sample collection were carried out: one in the early season (1-27 May 2015; hereafter "spring") to coincide with the oilseed rape bloom (Free and Ferguson 1980) and one in the late season (18 August-14 September 2015; hereafter "autumn") to coincide with late summer floral resource scarcity (Couvillon et al. 2014a). Sites were grouped into land-use types and a visit sequence constructed that equally distributed land-use types across the 4 weeks of the experiment with timings of visit within week depending on beekeeper availability, with a maximum of three apiaries visited each day. Each site was visited once in each period in approximately the same order. Sample collection was carried out between 10:00 and 17:00 on suitable days (> $12{ }^{\circ} \mathrm{C}$, wind speed $<20 \mathrm{kmh}$ ). Samples were collected from one (queenright) hive per apiary, selected as the left-most hive from the apiary entrance. Site data for each apiary included GPS coordinates, number of hives in the apiary and number of colonies surviving the previous winter. Hive data included hive type (National, Commercial etc.) and disease treatment history since 2013. Colony strength (bee-covered surface) was estimated following standard methods by counting the number of sides of frames in which more than $50 \%$ of the surface area was covered with bees and recording the size (deep/shallow) and type (National, Commercial etc.) of frame to allow later calculation of covered surface area (Delaplane et al. 2013).

Thirty returning foragers were collected at the hive entrance to test for Nosema sp. (foragers are more likely to harbour the parasite; Fries et al. 2013). Taking 300 nurse bees per colony, the level of Varroa destructor mite infestation was assessed using the icing sugar shake method (Macedo et al. 2002). A frame from the lowest brood box containing brood at all stages and freshly stored pollen was shaken into a washtub and the flying bees allowed to leave. A cup of $\mathrm{c}$. 300 bees $(100 \mathrm{ml})$ was collected and tipped into a jar containing 1-tbsp icing sugar (Tate \& Lyle, London, UK). This was rolled to ensure all bees were covered in sugar and left for $5 \mathrm{~min}$ in the shade, after which the icing sugar was shaken through the lid of the jar (size 8 hardware mesh) into a resealable plastic food bag. This was later dissolved in water, the number of mites counted three times and the mode taken.

We collected pollen samples from beebread as this has been shown to provide similar data to that derived from pollen traps and can be collected in a single hive visit (Dimou and Thrasyvoulou 2007). From the same frame as the Varroa samples, we followed the protocol of Tsvetkov et al. (2017) and used a spatula (width $=5 \mathrm{~mm}$ ) to collect freshly stored pollen from thirty cells which was then placed in individual Eppendorf tubes per cell. Pollen cells were selected on the basis of freshness (powdery texture, no nectar seal). This pollen was likely to have been collected within 2 weeks prior to sampling (Vásquez and Olofsson 2009). All of 


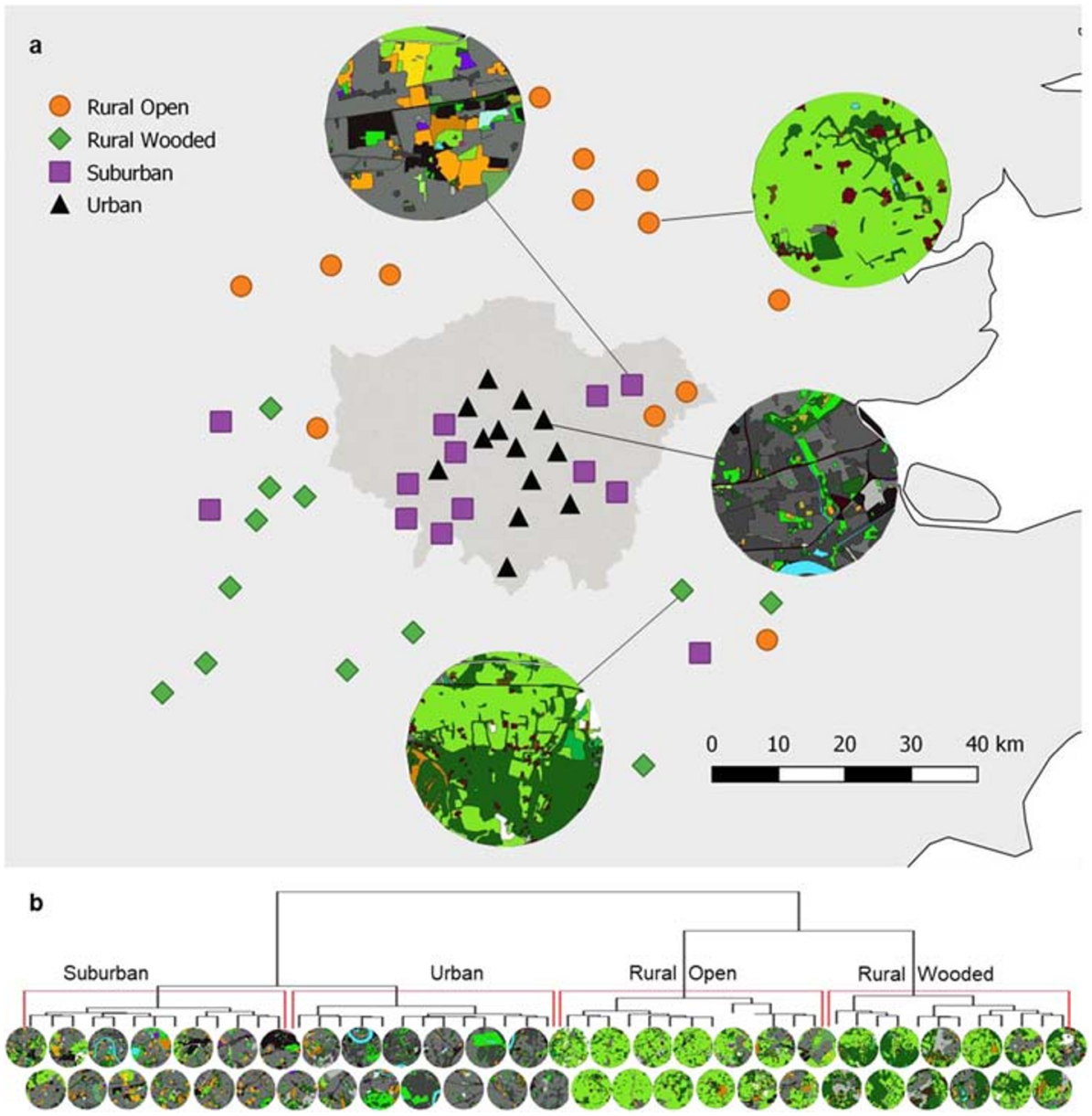

Figure 1. a Location of 51 apiary sites in SE England. The Greater London region is identified by dark grey shading, and inset circles show GIS land-use mapping for a representative site from each of the four land-use types (urban, suburban, rural open and rural wooded). Land-use map colours indicate 29 land classes; in summary, grey colours represent urban land classes (darker with increasing building density); green colours represent vegetated land including arable, pasture, woodland and urban parkland; orange colours represent sport and recreational open spaces; and blue colours represent water. b Cluster analysis (Ward's method) of land-use types of 51 sites located in SE England; branch terminals show land-use maps of individual sites generated from GIS classification.

the samples described above were placed immediately into dry ice and then into storage at $-80{ }^{\circ} \mathrm{C}$ within a maximum of 2 days.

\subsection{Pollen analysis and parasite screening}

A small portion of each pollen sample (total $=$ 2746 separate pollen samples) was mounted individually on a slide with water, basic fuchsin and glycerine jelly (Brunel Microscopes,
Chippenham, UK) on a hotplate set to $80{ }^{\circ} \mathrm{C}$. These were examined using a light microscope (Nikon Eclipse 50i) at $\times 400$ magnification and each pollen morphotype was given a unique number, differentiated by established pollen morphological characteristics such as size, exine structure, shape and number of apertures. Because each pollen sample came from a single cell and the sample was scraped from the top layer of beebread within the cell, samples were typically 
homogenous or overwhelmingly dominated by a single type, and as such we recorded a single pollen type per sample rather than collecting within-sample quantitative data. We therefore consider each pollen sample to approximately represent a single foraging trip. Pollen types were identified to morphotypes to generate diversity and species composition data. Where possible, we additionally identified pollen types to family, genus or species (spring: $50 \%$ of morphotypes identified; autumn: $49 \%$ ), on the basis of pollen morphology and colour using a combination of identification guides (Sawyer et al. 1981; Moore et al. 1991; Pollen-Wiki 2016; AutPal 2017). There is evidence to suggest that trees are an important pollen source for bees (Keller et al. 2005; Donkersley 2019), and the abundance of trees may differ between urban and rural areas. We therefore categorised identified pollen types as "woody" (trees and shrubs) or "non-woody" (herbs).

Pooled samples of 30 bees per colony were microscopically screened for Nosema sp. following Fries et al. (2013) and Human et al. (2013) to obtain information on colony-level Nosema sp. infection. We removed the abdomens of 30 frozen bees per colony and ground them with $30 \mathrm{ml}$ distilled water. A 14- $\mu$ l aliquot of the suspension was transferred to a haemocytometer, and the number of spores in five squares was counted. We did not identify the spores to species as Nosema apis and Nosema ceranae cannot be reliably differentiated microscopically. To obtain the Nosema sp. load for 30 bees, the following formula was applied:

sample volume $(\mathrm{ml}) \times$

$$
\left(\frac{\text { total no.counted particles } \times \text { dilution factor }(\partial)}{\text { area of squares counted }\left(\mathrm{mm}^{2}\right) \times \text { chamber depth }(\mathrm{mm})}\right)
$$

\subsection{Statistical analysis}

Pollen species composition was analysed using PERMANOVA to investigate whether communities differed between land-use types in spring and autumn. For all other analyses, we followed an information theoretic approach to model selection (Grueber et al. 2011). We used an "all-subset" approach to build a comparison set that comprised (1) the basic null model containing only the constant and residual variance; (2) a full model containing combinations of the variables land use (urban, suburban, rural open or rural wooded), season (autumn or spring) and log-transformed apiary size (number of hives), their two-way interaction and colony strength (Varroa analysis only); and (3) all subsets of the full model. We selected the model with the lowest AICc as the best fitting model(s) (Johnson and Omland 2004) unless at least one alternative model was within two AICc units, in which case parameter estimates were based on conditional model averaging (Symonds and Moussalli 2011; Grueber et al. 2011). Where mixed models were appropriate, site was included as a random effect in the full model and all subsets. A single extreme observation whereby a single species (Impatiens glandulifera) made up all thirty pollen samples from one hive was removed from the analysis of "proportion of pollen from woody plants" because it undermined the assumptions of our models; including it did not change the outcome. Final models were validated graphically to assess fit and check that assumptions had been met (Zuur and Ieno 2011), and examined for spatial autocorrelation by using a Moran's $I$ test on the residuals and graphically assessing the spatial pattern of residuals. No evidence of spatial autocorrelation was found for any of the analyses.

Binomial GLMMs were performed to analyse the proportion of pollen collected from woody species. Pollen morphotype richness (for each hive) was analysed using GLMMs with Poisson error structure, and the Shannon diversity of pollen morphotypes was analysed with linear mixed models after scaling of the dependent variable. Colony strength (estimated bee-covered surface) was analysed using linear mixed models. Overwintering success, reported by beekeepers as a proportion of hives surviving the previous winter, was modelled using GLMs with a binomial error structure. Nosema infection and Varroa infestation were analysed using zero-altered Poisson hurdle models to deal with the zeroinflated dataset (hurdle function in $\mathrm{R}$ package pscl), where the response is modelled as two processes - a binomial process and a zero- 
truncated Poisson process (Zuur and Ieno 2011). Thus, the parameter estimates from the hurdle model provide information on both the binary probability of any infection (binomial process) and the number of spores/mites if infected (Poisson process). Nosema spore counts were cuberoot transformed prior to analysis. Final models containing categorical variables were rerun with each factor level coded as the baseline variable to investigate pairwise differences between factor levels (Te Grotenhuis and Thijs 2015; see Table S3). We carried out additional analyses to test the relationships between Varroa treatment, land use and Varroa infestation (see Supplementary Methods, Online Resource 1).

All analyses were conducted in $\mathrm{R}$ version 3.2.1 (R Core Team 2018) using packages MuMIn (Barton 2018), lme4 (Bates et al. 2015), pscl (Zeileis et al. 2008), vegan (Oksanen et al. 2018), betapart (Baselga et al. 2018), beeswarm (Eklund 2016) and Hmisc (Harrell Jr and Dupont 2018).

\section{RESULTS}

\subsection{Colony health}

Land category had a significant effect on colony strength (bee-covered surface), with the best model retaining only land category as a predictor (Figure 2a; $\triangle \mathrm{AICc}$ to next best model $=3.05$, Table S1a). Based on the pairwise interactions between land categories, we found model estimates of colony strength to be highest in suburban colonies followed by urban, rural wooded and lastly rural open (Table I(a)). Specifically, we found no statistical difference between the urban categories (urban parameter estimate with suburban as baseline [95\% CIs]: $-0.345[-1.041$ to $0.351]$ ); however, when using suburban as a baseline intercept, both rural categories were significantly lower (rural open estimate with suburban as baseline: -1.446 [ -2.121 to -0.771$]$; rural open estimate with suburban as baseline: -0.722 [1.411 to -0.034$]$ ), and with urban as a baseline, we found rural open to be significantly lower (estimate: $1.101[-1.784$ to -0.481$]$ ). Only apiary size affected overwintering success, with a positive relationship between apiary size and success (Table S2b).
Land category had a significant effect on Nosema spore count in hives, with highest prevalence in both rural categories in the autumn (Figure 2b). Nosema infection was analysed through hurdle models in which the count process models spore count, and the binomial process probability of infection. The binary probability of infection did not differ significantly between sites (only "Apiary size" was retained in the binomial process within the final model set; Table I). However, land category, season and their interaction were all retained within the count process of every model in the candidate set (Table I). In the autumn, both rural open and wooded sites showed significantly higher spore count than urban and suburban sites (rural open parameter estimate with urban as baseline: 0.397 [0.275 to 0.519 ]; rural wooded parameter estimate with urban as baseline: 0.310 [0.186 to 0.433 ]; Table S3e). Smaller but significant differences were found between land categories in the spring, with suburban displaying lower Nosema prevalence than urban and rural open (urban parameter estimate with suburban as baseline: 0.190 [0.072 to 0.307]; rural open estimate with suburban as baseline: 0.218 [0.102 to 0.334]; Table S3e, Figure 2b).

Land category had an effect on Varroa mite counts in those colonies that contained Varroa (count process of the hurdle model) but not on the probability that colonies would contain Varroa (binomial process). Land category, season and their interaction along with apiary size and colony strength were all retained in the count process but only season was retained in the binomial process of the best model ( $\triangle \mathrm{AICc}$ to next best model $=2.0$; Table S1b). Unlike for Nosema, hives in all land categories showed higher Varroa mite counts in autumn than spring (autumn parameter estimate with urban and spring as baseline: 2.227 [1.705 to 2.750], Table S3d, Figure 2). There was no consistent effect of urbanisation, with the highest autumn counts in urban and rural wooded colonies (suburban parameter estimate with urban as baseline: $-0.604[-0.790$ to 0.417]; Table S3d, Figure 2c). In contrast, in spring, Varroa counts were lower in urban than all other land categories (suburban parameter estimate with urban as baseline: 0.841 [0.233 to 1.448]; rural open parameter estimate with urban 
A. E. Samuelson et al.

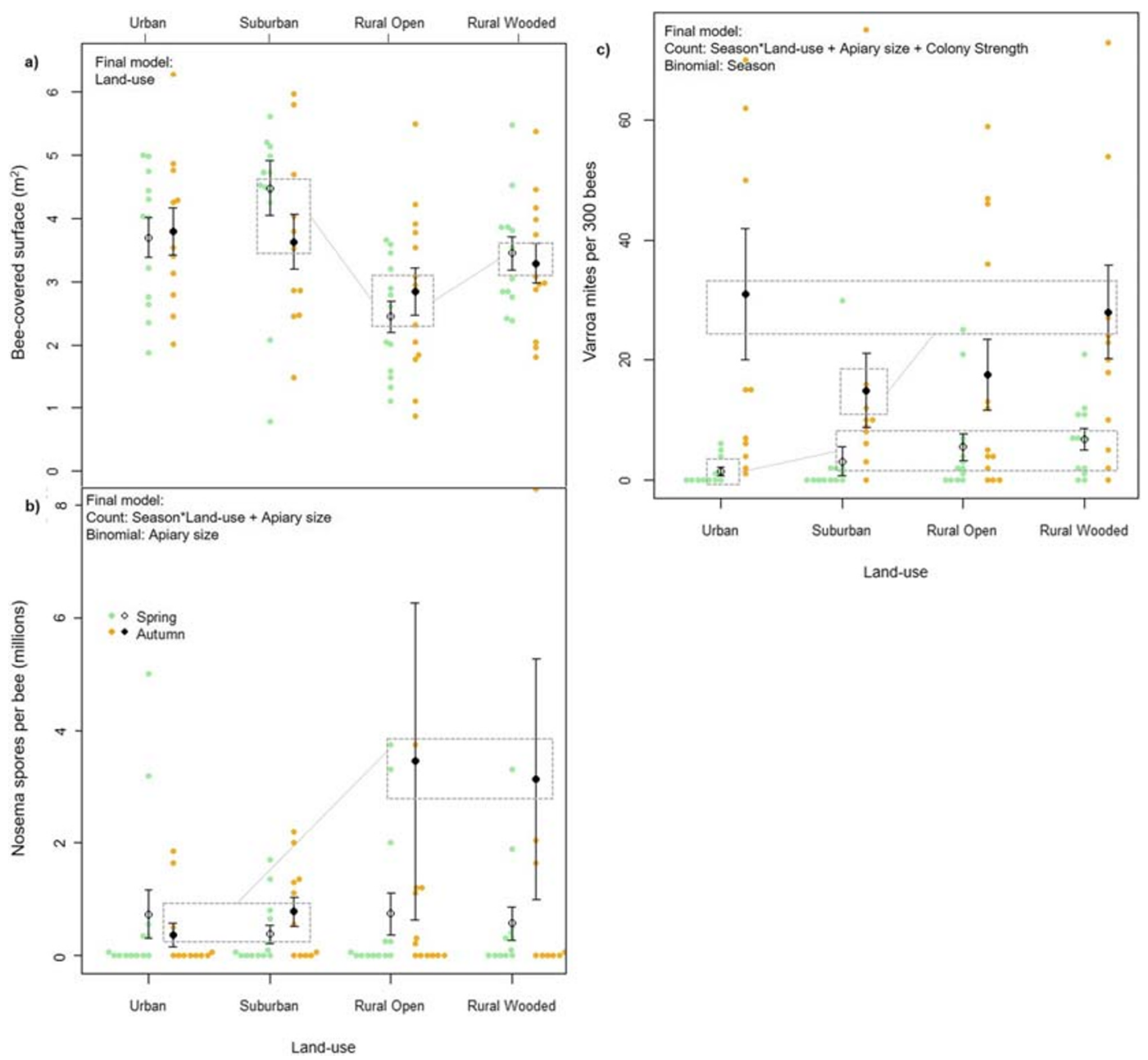

Figure 2. Means and standard errors for raw data for a colony strength, b Varroa mite count and $\mathbf{c}$ Nosema spore count across four land-use types in two periods, spring and autumn. Raw data are displayed as green (spring) and orange (autumn) points. Important significant pairwise differences with large effect sizes (see Table S3) are highlighted in grey boxes and variables included in the final model or model set are inset. LU land category.

as baseline: 1.123 [0.559 to 1.687$]$; rural wooded parameter estimate with urban as baseline: 0.942 [0.387 to 1.497]; Table S3d, Figure 2c).

\subsection{Pollen}

\subsubsection{Pollen richness and diversity}

Land category, season and their interaction along with apiary size all affected pollen morphotype richness (Table S1e), with higher richness in urban than rural open colonies (spring rural open parameter estimate with urban as baseline: -0.320 [ -0.586 to -0.054$]$; autumn rural open parameter estimate with urban as baseline: 0.316 [ -0.581 to -0.051$]$; Table S3b, Figure 3b). There was no effect on any of the measured variables on Shannon diversity (Figure 3c), with the null model showing the lowest AICc ( $\triangle \mathrm{AICc}$ to next best model: 3.26; Table S1f). 
Table I. (a-e) Coefficients and 95\% confidence intervals (CIs) for the optimal model or model sets (model averaged where applicable; see Table S1) for analyses where land use was included in the optimal model(s). Parameters highlighted in italics are considered important to the model (continuous variables) or significantly different from the baseline (categorical variables) based on 95\% CIs not crossing zero. All analyses shown have urban as the baseline for land use and autumn as the baseline for season; for other baseline combinations see Table S3. (f) Results from PERMANOVA tests to analyse the effect of land use on pollen species composition in spring and autumn, and pairwise comparisons between land-use types in the spring

\begin{tabular}{|c|c|c|c|c|}
\hline \multicolumn{5}{|c|}{ (a) Colony strength } \\
\hline \multirow[t]{2}{*}{ Parameters } & \multirow[t]{2}{*}{ Estimate } & \multirow[t]{2}{*}{ Std. error } & \multicolumn{2}{|c|}{$95 \%$ CIs } \\
\hline & & & Lower & Upper \\
\hline (Intercept) & 3.742 & 0.254 & 3.244 & 4.239 \\
\hline Land use (suburban) & 0.345 & 0.355 & -0.351 & 1.041 \\
\hline Land use (rural open) & -1.101 & 0.349 & -1.784 & -0.418 \\
\hline \multirow[t]{2}{*}{ Land use (rural wooded) } & -0.377 & 0.355 & -1.073 & 0.319 \\
\hline & (b) Nosem & & & \\
\hline \multirow[t]{3}{*}{ Parameters } & Estimate & Std. error & \multicolumn{2}{|c|}{$95 \%$ CIs } \\
\hline & & & Lower & Upper \\
\hline & \multicolumn{4}{|c|}{ Count process } \\
\hline (Intercept) & 4.499 & 0.057 & 4.387 & 4.611 \\
\hline Apiary size & -0.015 & 0.018 & -0.050 & 0.021 \\
\hline Season (spring) & 0.126 & 0.069 & -0.010 & 0.262 \\
\hline Land use (suburban) & 0.109 & 0.065 & -0.019 & 0.237 \\
\hline Land use (rural open) & 0.397 & 0.062 & 0.275 & 0.520 \\
\hline Land use (rural wooded) & 0.309 & 0.063 & 0.186 & 0.433 \\
\hline Land use (suburban): season (spring) & -0.350 & 0.090 & -0.528 & -0.173 \\
\hline Land use (rural open): season (spring) & -0.422 & 0.087 & -0.592 & -0.252 \\
\hline \multirow[t]{2}{*}{ Land use (rural wooded): season (spring) } & -0.467 & 0.087 & -0.638 & -0.295 \\
\hline & \multicolumn{4}{|c|}{ Binomial process } \\
\hline (Intercept) & -0.251 & 0.495 & -1.222 & 0.720 \\
\hline \multirow[t]{2}{*}{ Apiary size } & 0.440 & 0.283 & -0.115 & 0.994 \\
\hline & (c) Varroa & & & \\
\hline \multirow[t]{3}{*}{ Parameters } & Estimate & Std. error & \multicolumn{2}{|c|}{$95 \%$ CIs } \\
\hline & & & Lower & Upper \\
\hline & \multicolumn{4}{|c|}{ Count process } \\
\hline (Intercept) & 3.809 & 0.069 & 3.674 & 3.944 \\
\hline Apiary size & -0.304 & 0.038 & -0.378 & -0.230 \\
\hline Season (spring) & -2.295 & 0.266 & -2.816 & -1.773 \\
\hline Land use (suburban) & -0.594 & 0.095 & -0.780 & -0.407 \\
\hline Land use (rural open) & -0.187 & 0.087 & -0.358 & -0.017 \\
\hline Land use (rural wooded) & 0.074 & 0.078 & -0.079 & 0.227 \\
\hline Land use (suburban): season (spring) & 1.548 & 0.323 & 0.915 & 2.181 \\
\hline Land use (rural open): season (spring) & 1.212 & 0.299 & 0.626 & 1.798 \\
\hline \multirow[t]{2}{*}{ Land use (rural wooded): season (spring) } & 0.886 & 0.294 & 0.311 & 1.462 \\
\hline & \multicolumn{4}{|c|}{ Binomial process } \\
\hline (Intercept) & 2.128 & 0.473 & 1.201 & 3.055 \\
\hline
\end{tabular}


Season (spring)

$$
\begin{array}{lll}
-1.757 & 0.555 & -2.845
\end{array}
$$

(d) Proportion woody pollen

Parameters

(Intercept)

Apiary size

Season (spring)

Land use (suburban)

Land use (rural open)

Land use (rural wooded)

Land use (suburban): season (spring)

Land use (rural open): season (spring)

Land use (rural wooded): season (spring)

Parameters

(Intercept)

piary size

Season (spring)

Land use (suburban)

Land use (rural open)

Land use (rural wooded)

Land use (suburban): season (spring)

Land use (rural open): season (spring)

Land use (rural wooded): season (spring)
Estimate

$$
-1.823
$$$$
-0.366
$$

4.684

0.259

$-0.653$

$-0.159$

0.280

$-1.030$

$-1.014$

(e) Pollen species richness
0.447

Std. error

0.184

0.353

0.480

0.491

0.482

0.487

0.450

0.449

Std. error

2.041

0.115

$-0.055$

0.061

$-0.102$

0.101

$-0.076$

0.158

$-0.316$

0.135

$-0.186$

0.134

$-0.422$

0.220

$-0.019$

0.226

0.045

0.220

(f) Pollen species composition (PERMANOVA)

Overall

Spring

Autumn
F

3.653

1.269
$95 \%$ CIs

$\begin{array}{ll}\text { Lower } & \text { Upper } \\ -2.699 & -0.947 \\ -0.727 & -0.005 \\ 3.991 & 5.376 \\ -0.682 & 1.200 \\ -1.615 & 0.309 \\ -1.104 & 0.785 \\ -0.675 & 1.234 \\ -1.912 & -0.148 \\ -1.895 & -0.134\end{array}$

$95 \%$ CIs

Lower

Upper

1.814

2.267

$-0.174$

0.064

$-0.299$

0.095

$-0.386$

0.233

$-0.581$

$-0.051$

$-0.448$

0.076

$-0.854$

0.010

$-0.461$

0.424

$-0.386$

0.477

$R^{2}$

$p$ value

0.199

0.005

0.029

0.159

Pairs (spring)

Suburban vs urban

3.742

0.145

0.003

Suburban vs rural open

6.609

0.223

0.001

Suburban vs rural wooded

2.821

0.109

0.008

Urban vs rural open

4.578

0.179

0.001

Urban vs rural wooded

3.114

0.129

0.007

1.464

0.062

0.190

\subsubsection{Morphotype composition}

In spring, the five most common pollen types in each land category made up on average $75.7 \pm \mathrm{SE}$ $3.0 \%$ of samples across land categories compared to $48.8 \pm 2.6 \%$ in autumn (Figure $4 \mathrm{c}$ ). Springcollected pollen composition differed significantly between land categories (PERMANOVA, $d f=3$, $F=3.6, p=0.005)$. Pollen morphotype composition did not significantly differ between rural wooded and rural open land categories, but composition in these land categories differed significantly from those in urban and suburban, which also differed from each other (Figure 5a; Table I(f)). In the autumn, collected pollen composition was not significantly affected by land category (PERMANOVA, $d f=1, F=1.2, p=0.160$; Figure $5 \mathrm{~b})$. These differences were reflected in the 

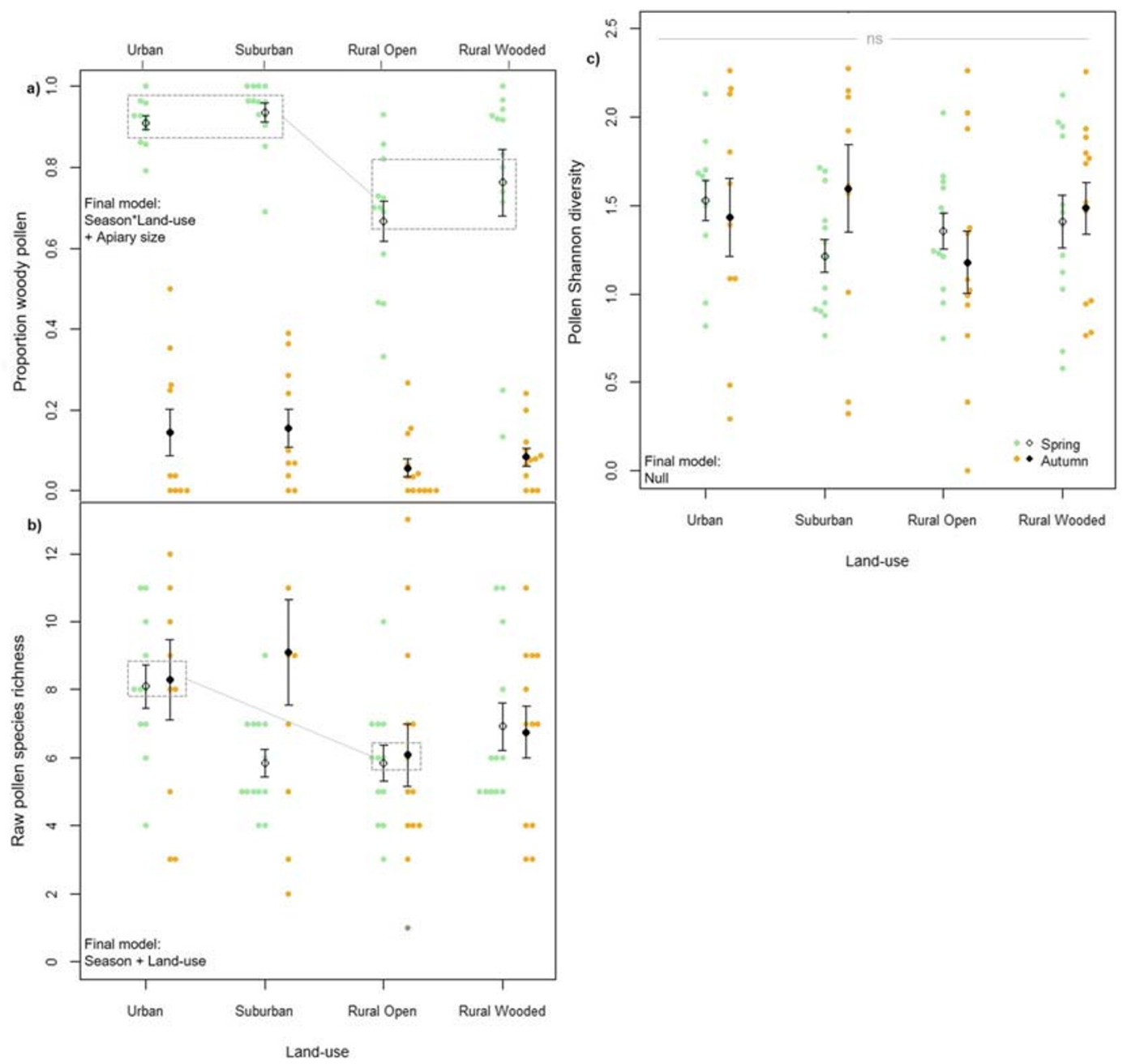

Figure 3. Means and standard errors for a proportion woody pollen, $\mathbf{b}$ pollen morphotype richness and $\mathbf{c}$ pollen Shannon diversity across four land-use types in two periods, spring and autumn. Raw data are displayed as green (spring) and orange (autumn) points. Important significant pairwise differences with large effect sizes (see Table S3) are highlighted in grey boxes and variables included in the final model or model set are inset.

differences between land catgeories in proportion of pollen collected from woody plants. Land category, season and their interaction along with apiary size affected the proportion of pollen collected from woody plants ( $\triangle \mathrm{AICc}$ to next best model: 7.64; Figure 3a, Table S1d). A significantly greater proportion of pollen was collected from woody plants in spring (mean \pm SE: $81.9 \pm 2.9 \%$ ) than in autumn (mean $10.5 \pm 1.9 \%$; autumn parameter estimate with spring and urban as baseline: 4.700
[4.004 to 5.395]; Table I(d), Table S3a). In spring, woody plants made up a greater proportion of collected pollen in urban and suburban than either rural land categories (rural open parameter estimate with suburban as baseline: $-2.220[-3.062$ to 1.379]; rural wooded parameter estimate with suburban as baseline: -1.728 [-2.591 to -0.865$]$ ) while in autumn, there were no significant differences between land categories (Table I(d), Table S3a). 


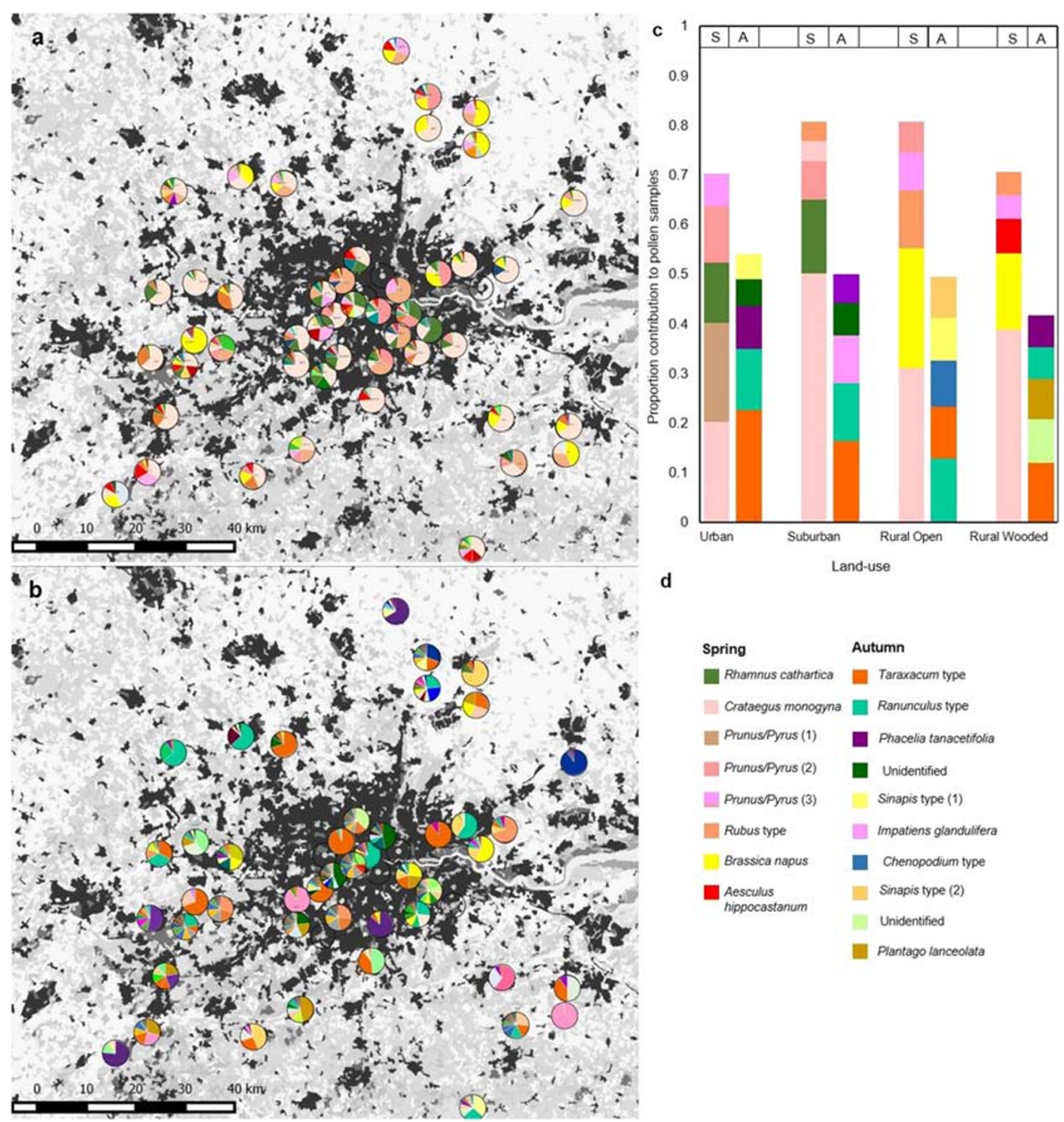

Figure 4. Contribution of different pollen types to pollen samples in each of 51 sites across SE England collected in a spring and $\mathbf{b}$ autumn. $\mathbf{c}$ Five most important pollen types (greatest contribution) in each of four land-use types in spring and autumn. d Colour legend for five most important pollen types in each land-use type. Additional pollen types and their colours are shown in the supplementary material (Online Resource 1).

\section{DISCUSSION}

We found positive effects of urban land use on honeybee colony strength and the raw morphotype richness of collected pollen, alongside lower late-season counts for Nosema sp. infection in hives from urban and suburban sites.
Colony strength was lower in rural open colonies than all other land-use types, a result that aligns with recent findings of lower bumblebee colony growth in colonies placed in agricultural sites compared to urbanised sites (Samuelson et al. 2018). This may be related to higher Nosema sp. infection in rural sites, which may have affected 


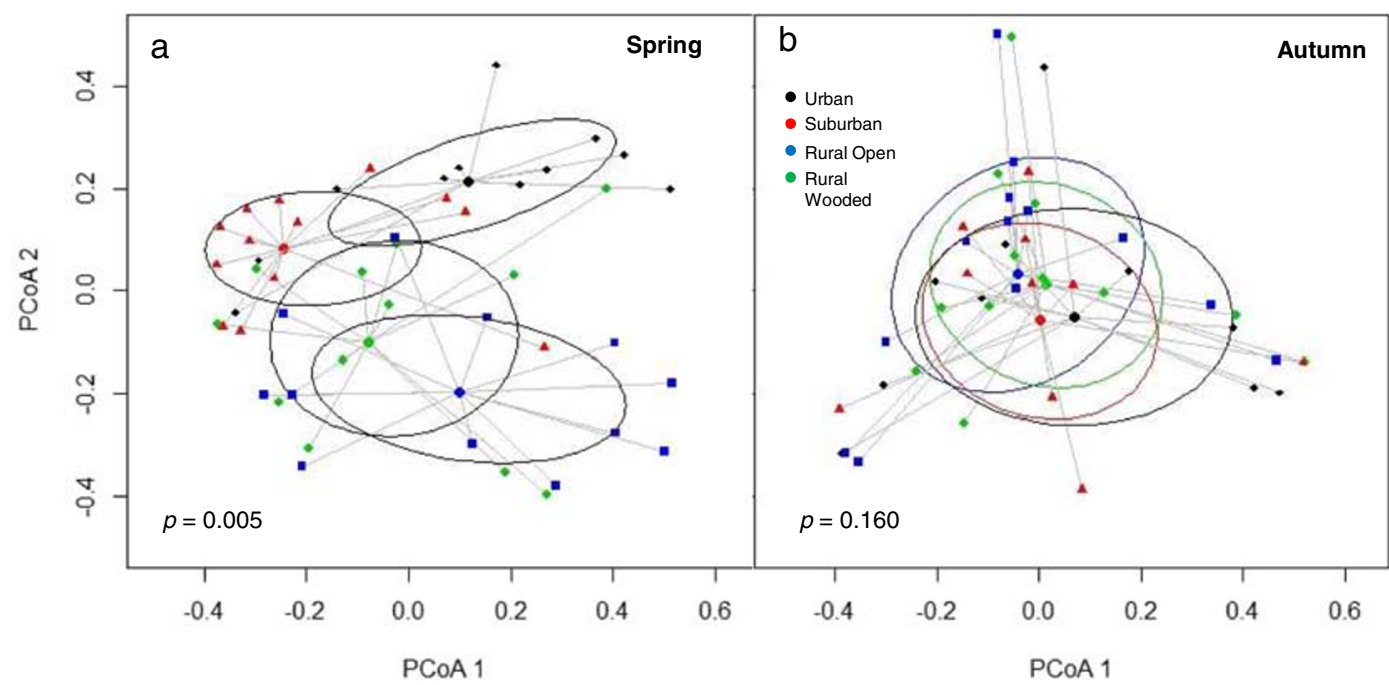

Figure 5. Principal coordinate analysis (PCoA) plots to visualise differences in pollen species composition in four land-use types in a spring and b autumn using Bray-Curtis distances (Beals 1984). Ellipses represent one standard deviation from the centroid and $p$ values from PERMANOVA analyses are inset. Points represent individual sites: urban (black diamonds), suburban (red triangles), rural wooded (green diamonds), rural open (blue squares).

colony growth (Genersch 2010). Lower forage availability in rural sites may also have limited colony growth (Garbuzov et al. 2015b; Lecocq et al. 2015 although cf. Sponsler and Johnson 2015; Sponsler et al. 2017). Moreover, nutritional quality (protein content) of honeybee-collected pollen has been reported to be higher in built-up areas (Donkersley et al. 2017). The presence of pesticide residues in the foraging landscape also has the potential to affect colony growth in honeybees (Tsvetkov et al. 2017; Woodcock et al. 2017; although cf. Rundlöf et al. 2015) and has been shown to be higher in rural than urban areas (Botías et al. 2017; Nicholls et al. 2018 although cf. Johnson and Pettis 2014).

Our finding of higher autumn Nosema sp. spore counts in rural sites relative to urbanised sites contradicts the findings from a US study which showed higher Nosema ceranae loads in honeybee colonies $(n=39)$ in more urbanised areas (Youngsteadt et al. 2015). The higher loads in hives at rural sites in our study could reflect a greater prevalence of Nosema sp. in the environment. This is plausible given the use of commercial bumblebee colonies in agricultural environments which have the potential to lead to pathogen spillover to honeybees visiting the same plants (Graystock et al. 2013; Fürst et al. 2014), and that more concentrated resource patches in agricultural areas such as mass-flowering crops could lead to increased localised bee densities (Requier et al. 2015) leading to pathogen transmission hotspots, a phenomenon that may be exacerbated in landscapes with little semi-natural habitat or other floral resources (Piot et al. 2019).

Varroa mite counts were higher in autumn (mean 22.7 mites per 300 bees) than spring (mean 4.2), following typical patterns of build-up over the season (Rosenkranz et al. 2010), but did not follow a consistent pattern with land use. In autumn, Varroa counts were highest in urban and rural wooded colonies, a result not driven by Varroa treatment (see Supplementary Results, Online Resource 1). Colony strength and apiary size affected Varroa counts, with higher Varroa counts in larger colonies and smaller apiaries. Local hive density (not measured here) may be a potential driver behind differences in parasite prevalence between land-use types. Horizontal disease transmission through drifting, robbing or shared foraging resources (Fries and Camazine 2001) may be increased in areas with higher colony densities, as has been shown for Paenibacillus larvae (American foulbrood) 
(Lindström et al. 2008), an important honeybee disease. Hive densities may be higher in urban than rural areas due to the popularity of urban beekeeping and increased human population density (Alton and Ratnieks 2013; Lorenz and Stark 2015), although varied apicultural and agricultural practices drive local and temporal differences in rural hive densities (Lindström et al. 2008). As such, future research should examine the relationship between differences in local honeybee colony density between urban and rural areas and disease prevalence.

Identification of the pollen collected by colonies highlights important forage plants in urban and rural areas and suggests that a richer variety of floral resources are available in cities, with raw morphotype richness (but not Shannon diversity) higher in urban than rural open colonies. This may be due to agricultural intensification reducing the available pollen sources in farmland areas (Lecocq et al. 2015) in contrast to the highly diverse array of exotic and native flowering plants available in urban gardens (Garbuzov and Ratnieks 2014). Pollen diet richness has implications for honeybee health (Dolezal and Toth 2018), supporting immune function and glucose oxidase activity (an enzyme involved in food store sterilisation; Alaux et al. 2010), reducing disease mortality (Di Pasquale et al. 2013) and promoting acquisition of beneficial gut microorganisms (Anderson et al. 2013; Corby-Harris et al. 2016). However, high diet richness may also indicate a lack of availability of high-volume resources such as mass-flowering crops, precluding bees from specialising on a small number of abundant species, as may be possible in agricultural areas (Rollin et al. 2013). Research indicates that honeybees in agricultural areas visit mass-flowering crops when they are available and then switch to semi-natural patches with less dense and more varied floral resources when the bloom is over (González-Varo and Vilà 2017; Samuelson et al. 2019), suggesting that a rich diet may be evidence that high-volume resources are unavailable.

Spring pollen morphotype composition was strongly differentiated by land-use type, with distinct urban, suburban and rural (open + wooded) groups, while in autumn, there was no difference in composition across land use, possibly because important pollen sources in autumn samples consisted of generalist plants such as Taraxacum (dandelion) and Ranunculus (buttercup) which are common weeds in both agricultural and urban landscapes (Sterry 2008; Hicks et al. 2016). In contrast, important spring sources were more likely to consist of agricultural or urban specialists, such as Rhamnus cathartica in urban (buckthorn, a common hedge plant; Kurylo and Endress 2007) and Brassica napus in rural areas (oilseed rape, a widespread agricultural crop; Garbuzov et al. 2015a). This is intensified by the fact that the five most important species made up a larger contribution (mean across land-use types $76 \%$ ) in spring than in autumn (mean 49\%), suggesting that colonies focussed collection more on these common plant sources in the spring than in the autumn. Spring pollen sources were dominated by woody plants (reflecting results from previous research; Keller et al. 2005; Donkersley 2019), and urban and suburban colonies collected a significantly higher proportion of woody pollen than rural colonies. This reliance on pollen from trees and shrubs in the spring, when demand for protein is high while colonies are building up brood (Keller et al. 2005), highlights the importance of urban trees in otherwise high-density builtup areas (Macivor et al. 2014). In rural areas, B. napus contributed a substantial proportion of spring-collected pollen. However, no colony fed exclusively on $B$. napus when it was available, with the highest proportion of B.napus pollen at $53 \%$ and the mean (excluding colonies containing no B. napus pollen) at $22.6 \pm$ $4 \%$ (reflecting the $14 \%$ average found in a study by Garbuzov et al. 2015a). This has implications for colony exposure to pesticides. Many studies calculate exposure assuming exclusive foraging on B. napus while it is in bloom (Whitehorn et al. 2012; Henry et al. 2012); our findings, like those of Garbuzov et al. (2015a), suggest that this would result in an overestimation of pesticide exposure. However, it is important to note that nectar collection may rely more heavily on mass-flowering crops than pollen (Samuelson et al. 2019; Requier et al. 2015). 
Our findings demonstrate largely positive effects of urbanisation on honeybee colony success, complementing a growing body of evidence suggesting that urban areas may also support populations of wild pollinators (Baldock et al. 2015; Hall et al. 2016; Samuelson et al. 2018). While this has positive implications for the recent rise in urban beekeeping (Lorenz and Stark 2015), it is important to note that our findings also serve to highlight the poor suitability of modern agricultural habitats for honeybees and many other pollinator taxa. Consequently, conservation efforts should focus on improving these habitats for pollinators.

\section{ACKNOWLEDGEMENTS}

We are grateful to the beekeepers who allowed access to their hives for this study, Kel Liu for help with parasite analysis and Mark Brown for advising on the study.

\section{AUTHOR CONTRIBUTIONS}

AS and EL designed the experiment. RG provided feedback on the design. AS performed the experiment and the statistical analyses, and wrote the manuscript draft. All authors provided the final edit.

\section{FUNDING INFORMATION}

A.E.S. is supported by the ICL-RHUL BBSRC DTP BB/M011178/1 and donations from High Wycombe Beekeepers' Association and Essex Beekeepers' Association. This research was also supported by the European Research Council under the European Union's Horizon 2020 Research and Innovation programme (Grant Agreement No. 638873). R.J.G.'s research is supported by the Grand Challenges in Ecosystems and the Environment Initiative at Silwood Park.

\section{COMPLIANCE WITH ETHICAL STANDARDS}

Conflict of interest The authors declare that they have no conflict of interest.

\section{OPEN ACCESS}

This article is licensed under a Creative Commons Attribution 4.0 International License, which permits use, sharing, adaptation, distribution and reproduction in any medium or format, as long as you give appropriate credit to the original author(s) and the source, provide a link to the Creative Commons licence, and indicate if changes were made. The images or other third party material in this article are included in the article's Creative Commons licence, unless indicated otherwise in a credit line to the material. If material is not included in the article's Creative Commons licence and your intended use is not permitted by statutory regulation or exceeds the permitted use, you will need to obtain permission directly from the copyright holder. To view a copy of this licence, visit http://creativecommons. org/licenses/by/4.0/.

L'urbanisation chez les abeilles s'accompagne d'une réduction de l'infection par Nosema sp., de plus de résistance de la colonie et une plus grande diversité du pollen collecté

Nosema spp. / Varroa destructor / recherche de pollen / résistance de la colonie

Urbanisation geht bei Honigbienen einher mit geringeren Nosema sp.-Infektionen, größerer Volksstärke und größerer Diversität des gesammelten Pollens

Nosema spp. / Varroa destructor / pollensammeln / volksstärke

\section{REFERENCES}

Aizen M.A., Harder L.D. (2009) The Global Stock of Domesticated Honey Bees Is Growing Slower Than Agricultural Demand for Pollination. Curr. Biol. 19, 915-918

Alaux C., Allier F., Decourtye A., Odoux J.-F., Tamic T., Chabirand M., Delestra E., Decugis F., Le Conte Y., Henry M. (2017) A 'Landscape physiology' approach for assessing bee health highlights the benefits of floral landscape enrichment and semi-natural habitats. Sci. Rep. 7, 40568

Alaux C., Ducloz F., Crauser D., Le Conte Y. (2010) Diet effects on honeybee immunocompetence. Biol. Lett. 6, 562-565 
Alton K., Ratnieks F.L.W. (2013) To bee or not to bee. Biologist 60, 12-15

Anderson K.E., Sheehan T.H., Mott B.M., Maes P., Snyder L., Schwan M.R., Walton A., Jones B.M., CorbyHarris V. (2013) Microbial Ecology of the Hive and Pollination Landscape: Bacterial Associates from Floral Nectar, the Alimentary Tract and Stored Food of Honey Bees (Apis mellifera). PLoS One 8, e83125

AutPal (2017) PalDat - Palynologische Datenbank. https://autpal.jimdo.com/. Accessed 18 Oct 2018

Baldock K.C.R., Goddard M.A., Hicks D.M., Kunin E., Mitschunas N., Osgathorpe L.M., Potts S.G., Robertson K.M., Scott A.V., Stone G.N., Vaughan I.P., Memmott J. (2015) Where is the UK's pollinator biodiversity? The importance of urban areas for flower-visiting insects. Proc. R. Soc. B Biol. Sci. 282, 20142849

Barton K (2018) MuMIn: Multi-Model Inference

Baselga A, Orme D, Villeger S, De Bortoli J, Leprieur F (2018) betapart: Partitioning Beta Diversity into Turnover and Nestedness Components

Bates D., Mächler M., Bolker B., Walker S. (2015) Fitting Linear Mixed-Effects Models Using $\{1 \mathrm{me} 4\}$. J. Stat. Softw. 67, 1-48

Beals E.W. (1984) Bray-Curtis Ordination: An Effective Strategy for Analysis of Multivariate Ecological Data. Adv. Ecol. Res. 14, 1-55

Botías C., David A., Hill E.M., Goulson D. (2017) Quantifying exposure of wild bumblebees to mixtures of agrochemicals in agricultural and urban landscapes. Environ. Pollut. 222, 73-82

Breeze T.D., Vaissière B.E., Bommarco R., Petanidou T., Seraphides N., Kozák L., Scheper J., Biesmeijer J.C., Kleijn D., Gyldenkærne S., Moretti M., Holzschuh A., Steffan-Dewenter I., Stout J.C., Pärtel M., Zobel M., Potts S.G. (2014) Agricultural policies exacerbate honeybee pollination service supply-demand mismatches across Europe. PLoS One 9

Brosi B.J., Delaplane K.S., Boots M., de Roode J.C. (2017) Ecological and evolutionary approaches to managing honeybee disease. Nat. Ecol. Evolut. 1, 1250-1262

Bunce R.G.H., Barr C.J., Clarke R.T., Howard D.C., Lane A.M.J. (1996) Land Classification for Strategic Ecological Survey. J. Environ. Manag. 47, 37-60

Corby-Harris V., Snyder L., Meador C.A.D., Naldo R., Mott B., Anderson K.E. (2016) Parasaccharibacter apium, gen. nov., sp. nov., Improves Honey Bee (Hymenoptera: Apidae) Resistance to Nosema. J. Econ. Entomol. 109, 537-543

Couvillon M.J., Schürch R., Ratnieks F.L.W. (2014a) Waggle Dance Distances as Integrative Indicators of Seasonal Foraging Challenges. PLoS One 9, e93495

Couvillon M.J., Schürch R., Ratnieks F.L.W.W., Eyl D., Ve S., Tez S., Carreck G.M., Samuelson E.E.W., Ratnieks F.L.W.W., Dalgleish T., Williams J.M.G., Golden A.M.J., Perkins N., Barrett L.F., Barnard P.J., Au Yeung C., Murphy V., Elward R. et al (2014b) Dancing bees communicate a foraging preference for rural lands in high-level agri-environment schemes. Curr. Biol. 24, $1212-1215$
Delaplane K.S., Van Der Steen J., Guzman-Novoa E. (2013) Standard methods for Apis mellifera research. J. Apic. Res. 52, 1-12

Di Pasquale G., Salignon M., Le Conte Y., Belzunces L.P., Decourtye A., Kretzschmar A., Suchail S., Brunet J.L., Alaux C. (2013) Influence of Pollen Nutrition on Honey Bee Health: Do Pollen Quality and Diversity Matter? PLoS One 8, e72016

Dimou M., Thrasyvoulou A. (2007) A comparison of three methods for assessing the relative abundance of pollen resources collected by honey bee colonies. J. Apic. Res. Bee World 46, 144-148

Dolezal A.G., Toth A.L. (2018) Feedbacks between nutrition and disease in honey bee health. Cur. Opin. Insect Sci. 26, 114-119

Donkersley P. (2019) Trees for bees. Agric. Ecosyst. Environ. 270-271, 79-83

Donkersley P., Rhodes G., Pickup R.W., Jones K.C., Power E.F., Wright G.A., Wilson K. (2017) Nutritional composition of honey bee food stores vary with floral composition. Oecologia 185, 749-761

Donkersley P., Rhodes G., Pickup R.W., Jones K.C., Wilson K. (2014) Honeybee nutrition is linked to landscape composition. Ecol. Evol. 4, 4195-4206

Eklund A (2016) beeswarm: The Bee Swarm Plot, an Alternative to Stripchart

Free J.B., Ferguson A.W. (1980) Foraging of bees on oilseed rape (Brassica napus L.) in relation to the stage of flowering of the crop and pest control. J. Agric. Sci. 94, 151

Fries I., Camazine S. (2001) Implications of horizontal and vertical pathogen transmission for honey bee epidemiology. Apidologie 32, 199-214

Fries I., Chauzat M.-P., Chen Y.-P., Doublet V., Genersch E., Gisder S., Higes M., McMahon D.P., MartínHernández R., Natsopoulou M., Paxton R.J., Tanner G., Webster T.C., Williams G.R. (2013) Standard methods for Nosema research. J. Apic. Res. 52, 1-28

Fürst M.A., McMahon D.P., Osborne J.L., Paxton R.J., Brown M.J.F. (2014) Disease associations between honeybees and bumblebees as a threat to wild pollinators. Nature 506, 364-366

Gago E.J., Roldan J., Pacheco-Torres R., Ordóñez J. (2013) The city and urban heat islands: A review of strategies to mitigate adverse effects. Renew. Sust. Energ. Rev. 25, 749-758

Garbuzov M., Couvillon M.J., Schürch R., Ratnieks F.L.W. (2015a) Honey bee dance decoding and pollen-load analysis show limited foraging on spring-flowering oilseed rape, a potential source of neonicotinoid contamination. Agric. Ecosyst. Environ. 203, 62-68

Garbuzov M., Ratnieks F.L.W. (2014) Quantifying variation among garden plants in attractiveness to bees and other flower-visiting insects. Funct. Ecol. 28, 364-374

Garbuzov M., Schürch R., Ratnieks F.L.W. (2015b) Eating locally: dance decoding demonstrates that urban honey bees in Brighton, UK, forage mainly in the surrounding urban area. Urban Ecosyst. 18, 411-418 
Genersch E. (2010) Honey bee pathology: Current threats to honey bees and beekeeping. Appl. Microbiol. Biotechnol. 87, 87-97

Goddard M.A., Dougill A.J., Benton T.G. (2010) Scaling up from gardens: biodiversity conservation in urban environments. Trends Ecol. Evol. 25, 90-98

González-Varo J.P., Vilà M. (2017) Spillover of managed honeybees from mass-flowering crops into natural habitats. Biol. Conserv. 212 , 376-382

Goulson D., Whitehorn P., Fowley M. (2012) Influence of urbanisation on the prevalence of protozoan parasites of bumblebees. Ecol. Entomol. 37, 83-89

Graystock P., Yates K., Evison S.E.F., Darvill B., Goulson D., Hughes W.O.H. (2013) The Trojan hives: Pollinator pathogens, imported and distributed in bumblebee colonies. J. Appl. Ecol. 50 , 1207-1215

Grotenhuis M Te, Thijs P (2015) Dummy variables and their interactions in regression analysis: examples from research on body mass index. ArXive

Grueber C.E., Nakagawa S., Laws R.J., Jamieson I.G. (2011) Multimodel inference in ecology and evolution: challenges and solutions. J. Evol. Biol. 24, 699-711

Grünewald B. (2010) Is Pollination at Risk? Current Threats to and Conservation of Bees. GAIA 19, 61-67

Hall D.M., Camilo G.R., Tonietto R.K., Ollerton J., Ahrn K., Arduser M., Ascher J.S., Baldock K.C.R., Fowler R., Frankie G., Goulson D., Gunnarsson B., Hanley M.E., Jackson J.I., Langellotto G., Lowenstein D., Minor E.S., Philpott S.M., Potts S.G. et al (2016) The city as a refuge for insect pollinators. Conserv. Biol. 31, 24-29

Hall O., Arnberg W. (2002) A method for landscape regionalization based on fuzzy membership signatures. Landsc. Urban Plan. 59, 227-240

Harrell Jr FE, Dupont C (2018) Hmisc: Harrell Miscellaneous

Henry M., Béguin M., Requier F., Rollin O., Odoux J.-F.F., Aupinel P., Aptel J., Tchamitchian S., Decourtye A. (2012) A common pesticide decreases foraging success and survival in honey bees. Science 336, 348-350

Hicks D.M., Ouvrard P., Baldock K.C.R., Baude M., Goddard M.A., Kunin W.E., Mitschunas N., Memmott J., Morse H., Nikolitsi M., Osgathorpe L.M., Potts S.G., Robertson K.M., Scott A.V., Sinclair F., Westbury D.B., Stone G.N. (2016) Food for Pollinators: Quantifying the Nectar and Pollen Resources of Urban Flower Meadows. PLoS One 11, e0158117

Human H., Brodschneider R., Dietemann V., Dively G., Ellis J.D., Forsgren E., Fries I., Hatjina F., Hu F.-L., Jaffé R., Jensen A.B., Köhler A., Magyar J.P., Özkýrým A., Pirk C.W.W., Rose R., Strauss U., Tanner G., Tarpy D.R. et al (2013) Miscellaneous standard methods for Apis mellifera research. J. Apic. Res. 52, 1-53

Johnson J.B., Omland K.S. (2004) Model selection in ecology and evolution. Trends Ecol. Evol. 19, 101108

Johnson J.D., Pettis J.S. (2014) A Survey of Imidacloprid Levels in Water Sources Potentially Frequented by
Honeybees (Apis mellifera) in the Eastern USA. Water Air Soil Pollut. 225, 2127

Keller I., Fluri P., Imdorf A. (2005) Pollen nutrition and colony development in honey bees: part 1 . Bee World 86, 3-10

Kurylo J., Endress A.G. (2007) Rhamnus cathartica: Native and naturalized distribution and habitat preferences. J Torrey Bot. Soc. 134, 420-431

Lecocq A., Kryger P., Vejsnæs F., Bruun Jensen A. (2015) Weight Watching and the Effect of Landscape on Honeybee Colony Productivity: Investigating the Value of Colony Weight Monitoring for the Beekeeping Industry. PLoS One 10, e0132473

Lindström A., Korpela S., Fries I. (2008) Horizontal transmission of Paenibacillus larvae spores between honey bee (Apis mellifera) colonies through robbing*. Apidologie 39, 515-522

Lorenz S., Stark K. (2015) Saving the honeybees in Berlin? A case study of the urban beekeeping boom. Environ. Sociol. 1, 116-126

Macedo P.A., Wu J., Ellis M.D. (2002) Using inert dusts to detect and assess varroa infestations in honey bee colonies. J. Apic. Res. 41, 3-7

Macivor J.S., Cabral J.M., Packer L. (2014) Pollen specialization by solitary bees in an urban landscape. Urban Ecosyst. 17, 139-147

Moore P.D., Webb J.A., Collison M.E. (1991) Pollen analysis. Blackwell Scientific Publications, Oxford

Nicholls E., Botías C., Rotheray E.L., Whitehorn P., David A., Fowler R., David T., Feltham H., Swain J.L., Wells P., Hill E.M., Osborne J.L., Goulson D. (2018) Monitoring Neonicotinoid Exposure for Bees in Rural and Peri-urban Areas of the U.K. during the Transition from Pre- to Post-moratorium. Environ. Sci. Technol. 52, 9391-9402

Oksanen J, Blanchet FG, Friendly M, Kindt R, Legendre P, McGlinn D, Minchin PR, O'Hara RB, Simpson GL, Solymos P, Stevens MHH, Szoecs E, Wagner H (2018) vegan: Community Ecology Package

Owen S.M., MacKenzie A.R., Bunce R.G.H., Stewart H.E., Donovan R.G., Stark G., Hewitt C.N. (2006) Urban land classification and its uncertainties using principal component and cluster analyses: a case study for the UK West Midlands S.M. Owen. Landsc. Urban Plan. 78, 1-39

Piot N., Meeus I., Kleijn D., Scheper J., Linders T., Smagghe G. (2019) Establishment of wildflower fields in poor quality landscapes enhances micro-parasite prevalence in wild bumble bees. Oecologia 189, 149-158

Pollen-Wiki (2016) Pollen-Wiki. http://pollen.tstebler. ch/MediaWiki/index.php?title=Pollen-Wiki:Über Pollen-Wiki. Accessed 18 Oct 2018

Potts S.G., Roberts S.P.M., Dean R., Marris G., Brown M.A., Jones R., Neumann P., Settele J. (2010) Declines of managed honey bees and beekeepers in Europe. J. Apic. Res. 49, 15-22

R Core Team (2018) R: A Language and Environment for Statistical Computing 
Requier F., Odoux J.F., Tamic T., Moreau N., Henry M., Decourtye A., Bretagnolle V., Odoux J.-F., Mickaë M., Henry M. (2015) Honey bee diet in intensive farmland habitats reveals an unexpectedly high flower richness and a major role of weeds. Ecol. Appl. 25, 881-890

Rollin O., Bretagnolle V., Decourtye A., Aptel J., Michel N., Vaissière B.E., Henry M. (2013) Differences of floral resource use between honey bees and wild bees in an intensive farming system. Agric. Ecosyst. Environ. $179,78-86$

Rosenkranz P., Aumeier P., Ziegelmann B. (2010) Biology and control of Varroa destructor. J. Invertebr. Pathol. 103, S96-S119

Rundlöf M., Andersson G.K.S., Bommarco R., Fries I., Hederström V., Herbertsson L., Jonsson O., Klatt B.K., Pedersen T.R., Yourstone J., Smith H.G. (2015) Seed coating with a neonicotinoid insecticide negatively affects wild bees. Nature 521, 77-80

Samuelson A.E., Gill R.J., Brown M.J.F.F., Leadbeater E. (2018) Lower bumblebee colony reproductive success in agricultural compared with urban environments. Proc. R. Soc. B Biol. Sci. 285, 20180807

Samuelson A.E., Leadbeater E. (2018) A land classification protocol for pollinator ecology research: An urbanization case study. Ecol. Evol. 8, 5598-5610

Samuelson AE, Schürch R, Leadbeater E (2019) Dancing bees evaluate agricultural forage resources as inferior to central urban land. bioRxiv Ecology. https://doi. org/10.1101/2019.12.19.882076

Sawyer R., Pickard R.S., Robert S. (1981) Pollen identification for beekeepers. University College Cardiff Press, Cardiff

Seto K.C., Güneralp B., Hutyra L.R. (2012) Global forecasts of urban expansion to 2030 and direct impacts on biodiversity and carbon pools. Proc. Natl. Acad. Sci. U. S. A. 109, 16083-16088

Smart M., Pettis J., Rice N., Browning Z., Spivak M. (2016) Linking Measures of Colony and Individual Honey Bee Health to Survival among Apiaries Exposed to Varying Agricultural Land Use. PLoS One 11, e0152685

Sponsler D., Johnson R. (2015) Honey bee success predicted by landscape composition in Ohio, USA. PeerJ 3 , e838

Sponsler D.B., Matcham E.G., Lin C., Lanterman J.L., Johnson R.M. (2017) Spatial and taxonomic patterns of honey bee foraging: A choice test between urban and agricultural landscapes. J Urban Ecol. 3 , 1-7
Sterry P. (2008) Collins complete guide to British wild flowers: a photographic guide to every common species. Collins, London

Symonds M.R.E., Moussalli A. (2011) A brief guide to model selection, multimodel inference and model averaging in behavioural ecology using Akaike's information criterion. Behav. Ecol. Sociobiol. 65 , 13-21

Theodorou P., Radzevic R., Murray E., Paxton R.J., Schweiger O. (2016) Pollination services enhanced with urbanization despite increasing pollinator parasitism. Proc. R. Soc. B Biol. Sci. 283, 20160561

Tsvetkov N, Samson-Robert O, Sood K, Patel HS, Malena DA, Gajiwala PH, Maciukiewicz P, Fournier V, Zayed A (2017) Chronic exposure to neonicotinoids reduces honey bee health near corn crops. Science 356:1395 LP-1397

United Nations (2018) World Urbanization Prospects: The 2018 Revision. United Nations, New York

Vásquez A., Olofsson T.C. (2009) The lactic acid bacteria involved in the production of bee pollen and bee bread. J. Apic. Res. 48, 189-195

Whitehorn P.R., O'Connor S., Wackers F.L., Goulson D. (2012) Neonicotinoid pesticide reduces bumble bee colony growth and queen production. Science 336, 351-352

Wood T.J., Goulson D. (2017) The environmental risks of neonicotinoid pesticides: a review of the evidence post 2013. Environ. Sci. Pollut. Res. 24, 17285-17325

Woodcock B.A., Bullock J.M., Shore R.F., Heard M.S., Pereira M.G., Redhead J., Ridding L., Dean H., Sleep D., Henrys P., Peyton J., Hulmes S., Hulmes L., Sárospataki M., Saure C., Edwards M., Genersch E., Knäbe S., Pywell R.F. (2017) Country-specific effects of neonicotinoid pesticides on honey bees and wild bees. Science (New York, N.Y.) 356, 1393-1395

Youngsteadt E., Appler R.H., López-Uribe M.M., Tarpy D.R., Frank S.D. (2015) Urbanization Increases Pathogen Pressure on Feral and Managed Honey Bees. PLoS One 10, e0142031

Zeileis A., Kleiber C., Jackman S. (2008) Regression Models for Count Data in $\{\mathrm{R}\}$. J. Stat. Softw. 27

Zuur A.F., Ieno E.N. (2011) Mixed Effects Models and Extensions in Ecology with R. Springer, New York

Publisher's note Springer Nature remains neutral with regard to jurisdictional claims in published maps and institutional affiliations. 